Colloquia Litteraria

UKSW

$4 / 2017$

DARIUSZ SEWERYN

\title{
"SLEEPING WITH THE EPIC POEM": POSSIBILITIES OF RESEARCH ON NORWID'S EROTIC IMAGINATION
}

The solidified position in research reception of Norwid as the most 'contemporary' of the great Romantics is based mostly on the discursive layer of his writings. S,o a lot of attention has been focused on solemn presentations of Norwid's views on most specific moral, philosophical, theological, political, social and aesthetic issues; and although the reflection on features of his poetic language and his graphic works has also developed while individual Norwid's texts are the subjects of controversies and interpretative debates, the issue of his poetic imagination has been rarely raised. Even the so called personal lyrics of Norwid are willingly read as moralistic discourse. However, Norwid is much more difficult to conceive of as a phantasmal poet. Without exaggerating this aspect in the holistic perspective of Norwid's works, we could, after all, attempt such a reflection.

There are relatively very few love lyrics in Norwid's oeuvre. It is quite symptomatic that out of two hundred and forty eight items in the volume on Romantic love Biblioteka Romantyczna (Romantic Library) there is not a single fragment of Norwid's texts. Is it so that this theme was outside the bounds of the programme dispute Norwid had with the first generation of Romantic poets?

The very fact that Norwid so persistently returned to the issue of the lack of full and mature female characters in Polish literature, and the high irony with which he treated women in Mickiewicz's texts, allow us to perceive in such utterances a sign of permanent polemic intention. 
As I regard the discursive approach as at least one-sided, I must stress that I am not going to focus here on Norwid's ideas and attitudes, but more on an area of imagination, difficult to perceive, in which Norwid's ideas had their grounding and out of which they drew their means of expression.

Although the erotic sphere of Norwid's artistic imagination does not seem to be particularly extensive and varied, there have appeared voices of Norwid scholars, which might incline us to approach the issue with deep consideration. Zygmut Wasilewski, in a book published in 1935, came up with an argument both inspiring and difficult to prove:

If there is no woman, then a text sounds as if Norwid was reading it to a woman. If there is no eroticism, then the poet's attitude is as if he counted that his recipient and judge is a woman in a parlour, spellbound by the magic of words and eagerly giving up understanding of content for male accents. ${ }^{1}$

Wasilewski's observation belongs to a category of observations which cannot be directly verified in any methodological way, but which have undeniable hermeneutic values. That is the reason why it is even more worthwhile to focus on things in Norwid's texts which are more tangible, although not obvious.

First of all, it should be stated that Norwid's noble declarations on the role of women in social life are, at times, somewhat double-edged. In a treatise entitled "Emancipation of Women" he wrote:

[...] a woman, being the liveliest of bindings between a lonely 'I' and a public 'We', becomes a first priestess naturally immolating egoism and giving ground to the common social body. ${ }^{2}$

(VI, 653)

\footnotetext{
1 Z. Wasilewski, Norwid, Warszawa 1935, 99.

2 Quotations from Norwid's texts are from this edition: C. Norwid, Pisma wszystkie, ed. by Juliusz Wiktor Gomulicki, vol. I-XI, Warszawa 1971-1976.
} 
The hidden presupposition of the presented judgement is an assumption that this 'lonely I'; is a male 'I', while an intrinsic, independent female ' $\mathrm{I}$ ' is not even taken into consideration. Therefore, a woman is not an autonomous subject (who could have, so to say, her own problems), but only an idealized social function, a mediating factor in relations between a man and society. Besides, she is like proverbial music-it soothes the savage beast. At the same time, however, Norwid claimed that:

A woman (in our opinion) is an organization naturally superior to a man. ${ }^{3}$

This "natural superiority", per saldo, however, is not necessarily good for them. As Norwid wrote:

[...] therefore, superiority, being inborn, is a natural privilege and is real; it is natural to aristocracy, and therefore in the context of acquired male superiority must have detrimental aspects (not for her, but for her advantages). Because our advantages always have their detrimental aspects. ${ }^{4}$

In consequence, natural superiority turns out to be cultural inferiority-that is the meaning of Norwid's argument.

As I have mentioned, tracing Norwid's ideas, expressed explicitly, is not a goal in itself in this paper. I would like only to draw attention to two features of the approach to the problem presented here: firstly to the non-autonomous and only mediating social role of a woman; secondly to the fact that the basic analytical categories of the discourse discussed here are marked by the opposition: superiority-inferiority.

In Norwid's oeuvre there exists a group of lyric texts which might be called parlour poems. A certain motif returns there, which could be described with this formula: conversation marked with a one-sided erotic aspect. A poem entitled "Malarz z konieczności" ("A Painter Out of Necessity"), dated 1860, is particularly clear in this respect,

3 Ibidem.

4 Ibidem. 
and its dialogic structure shows a fundamental hiatus of perspectives between the pair or lyric protagonists, defined with the pronouns 'I' and 'she'. A man has a very precise plan for this conversation:

Pa n i - mam mówić z nią o rytmie sił,

K tó r e sprawują planet korowody.

Każże mi podać wina - abym pil,

Cukru i wody -

$$
(I, 316)^{5}
$$

"To speak with her", as it turns out, is only a polite formula. In reality the man intends to speak to her. What is more, he is equipped with a full and detailed script with the project of scenography included within it:

I siądź - na ramię zarzuciwszy szal,

Nieumiejętnie, jak nimfy szal kładą:

Błękitną niechaj on harmonią fal

Jak z s k a ł y spada kaskadą!-

Firankę - sługa niech odrzuci z szyb,

Księżyc potrzebny jest k'temu,

Naczynie szklanne złotych

pełne ryb

Podamy jemu. ${ }^{6}$

Unfortunately, the female listener is not keen to play the role prepared for her:

Owszem, lecz spiesz się, właśnie bowiem czas,

Gdy fryzjer, Pinettim zwany,

\footnotetext{
5 "Madam - I am to talk with you about the rhythm of powers, / Which are governed by planets' processions./Order them to give me wine - so that I will drink,/ Sugar and water."

6 "And sit down, with a shawl drawn on your shoulder,/Not skilfully, as nymphs do,/Let it with a blue harmony of waves,/Cascade from rocks!/Let a servant draw a curtain away from the windows, /You need a moon for this,/A vessel full of golden fish,/We will give to it.".
} 
Przyjdzie - a za nim służebnice wraz

Mnogie przyniosą falbany. ${ }^{7}$

The man undertakes one more attempt to control the situation and proposes a different theme for his speech:

Pani - mam mówić z nią o głosce $A$,

Ile przyniosła ludzkości?! -

Wspomnę, co mądrość? a co znaczy łza?

Nadmienię też o miłości. ${ }^{8}$

The man has a project connected with scenography prepared also for this situation:

Siądźże - i włosy swe grzebieniem zbierz,

Gdy ja - przylegnę na progu;

I będę, jak do feodalnych wież,

Śpiewał: nieznanej i Bogu. ${ }^{9}$

But, again, this proposal is not welcomed with the expected enthusiasm:

Owszem - lecz śpiesz się, oto bowiem, kwiat

Nie będąc na czas zrobiony,

Odmieniać muszę włosów tok i szat,

Wieczór mój! - prawie stracony! ${ }^{10}$

Instead of a staged monologue on issues metaphysical and moral, the man must be content with making a pencil sketch of her, drawn 'from nature'.

\footnotetext{
7 "Yes, but hurry, as time/When a hairdresser called Pinetti/Will come - and afterwards,/Servants will bring many frills.

8 "Madam - I am to talk with you about the sound $A$,/How much has it brought to humanity?!/I will recollect what is wisdom. And what is a tear?/I will also mention love.

9 "Sit down, and gather your hair with a comb,/When I lie down in a threshold,/ And will like to feudal towers,/Sing: to the unknown and to God."

10 Of course-but hurry up, because, the flower/If it is not made on time,/I must change the order of hair and clothes,/My evening!-almost lost.
} 
The conclusion that the motivation for the conversational attempts of the protagonist has an erotic hue is based on the observation that if it were not so, the speaker would be acting in the role of a private teacher trying to give the lady a prescribed lesson, while his listener would resemble an absent minded and capricious pupil. Because such a concrete solution would look ridiculous, we might assume that the man's attempts are motivated by an erotic interest in the person he addresses.

The sharp, satirical construction of the image of the womanin the manner of the 'fashionable wife' known in the period of the Enlightenment-does not mean unambiguously that the man is a 'positive protagonist'. Although there exists a possibility of including this text with the other ones in which Norwid made his critique of parlours from the perspective of an independent moralist, this would be an opportunistic move. Particularly in the context of the fact that the lyric protagonist, with his inclination to directing and scenography, also seems to be a slightly suspicious figure. $\mathrm{He}$ expects her to be fully obedient to his directions and to freeze in an appropriate pose. The role for her-although she does not play it-is the role of a dummy, a marionette, while the speaker reserves the main and practically the only role for himself in the whole performance. At the same time the ostentatious aestheticism displayed by the 'director' in the selection of props and poses appears to be slightly kitschy.

There is no doubt that the poem presents the situation of a fundamental lack of agreement between the protagonists, but is it one of the acts of the real drama of a misunderstood artist who also happens to be a commentator? Probably not-the satire seems to be double-edged. It is focused mostly on the lady, but the figure of the unfortunate lover is not free from a satirical edge. The lyric 'I' directs his project at the wrong person, showing a false understanding of the situation. His slightly aesthetic musings are contrasted with a prosaic, petty concreteness of the lady; the final effect is slightly comic, and it would be difficult to prove that Norwid had not intended it to be this way. So, this text as a semantic whole is ultimately marked with auto-irony. 
His argument, erudite and poetic at the same time, is treated as a potential tool for a flirt, but it fails completely; the monologue, or more precisely, the mono-drama, seductive in its intention, ends up in a total fiasco in view of the lady's elementary lack of the will to cooperate, and her focus on the imperative of changing her hairstyle and clothes. This is proof of both her spiritual poverty and his naivety; he finally sees the futility of his performance and changes his tone into an equally indifferent one.

Let us stress two more circumstances: firstly, this poem, despite its humour and irony, shows the man being rejected by the woman in whom he is interested; secondly, the conversation with the woman looks like a speech to this woman.

A fragment of Norwid's letter to Cieszkowski may serve as an autocommentary to this poem.

Because the connection with society is through a woman (as you well know it ), and I will bore every woman within four hours: I will consider it correct that she tells banal things, she will consider it incorrect that I don't tell them.

(November, 1850, VIII, 111).

Starting with this example, I allow myself to state a general thesis: a characteristic feature of Norwid's literary imagination is an evocation of the situation of abasement experienced in an erotic context; this factor is connected with the verbal gestures of a protagonist being fulfilments of appropriate strategies of compensation. The biographical background of such phenomena in Norwid's writings is quite obvious, but the reduction of them to a biographical level is only very loosely connected with the history of literature. While analysing these themes I reach for psychological categories, not in order to deal with Norwid's personality, but more in order to reconstruct hidden features of the literary characters he created.

The first poem in which an active reaction to rejection of feelings is shown clearly is "Trzy strofki” (“Three Stanzas") from 1854, associated with the figure of Maria Kalergis: 
Nie bluźń, żem zranił Cię, lub jeszcze ranię,

Bom Ci ustąpił na mil sześć tysięcy;

I pochowałem łzy me, w Oceanie,

Na pereł więcej!..

$$
(\mathrm{I}, 222)^{11}
$$

The very opening line of the poem clearly presents the communicative situation: a lyric utterance starts with a protest, full of indignation, against some excuses or accusation of an addressee"don't blaspheme..." This is more like attack than defence. However, the attacking rhetorical potential of the speaking subject is not revealed. In the first line it is hidden behind the appearance of a defensive approach. Suffering caused by rejection takes on a discreet and noble form, and the conventionality of pearl metaphors intensifies a chivalric gesture of stepping down "by six thousand miles". But the pleasantries end in the second stanza.

I nie myśl! - jak Cię nauczyli w świecie

Świątecznych-uczućś w i ą t e c z n i - c z ci ci ele -

I nie mów, ziemskie iż są marne cele -

Lecz żyj - raz - przecie!...

$$
(\text { I b i d e m })^{12}
$$

The contempt in this speech is hard to miss. A few years earlier Norwid wrote to Maria Trębicka:

But I will tell you in confidence, which is unrivalled - because it may verge on impoliteness - that for all your sex, que pour la femme EN GENERAL, I have just one emotion: tender contempt. And what are you going to do with me for this?

(17 June 1847, VIII, 49)

11 "Don't blaspheme, that I have hurt you or that I am still hurting you,/Because it was I who stepped down by six thousand miles,/And I have hidden my tears in the ocean,/For more pearls."

12 "And don't think! - as they have taught you in the world/holiday emotions, holiday worshippers -/And don's say that earthly goals are bad,/But live! - once - really." 
But in order to understand properly what goes on in the second stanza of "Three Stanzas", such an understanding of the biographical context-although quite common in Norwid studies-is at least insufficient. The fixation of Norwid's feeling on the person of Maria Kalergis was really long lasting, because as late as in 1853 he wrote from New York to Maria Trębicka:

In vain!-truly, I love a woman the memory of whom is a stronger emotion than the love, friendship and real presence of others, and I love because this is love. It seems to me that this is clear, clear as lightning. (After 10 April 1853, VIII, 193).

If now we add to this some fragments from Norwid's writings critically assessing the 'angelic' aspect of women contemporary to him-the abusive sense of this stanza will nicely dovetail with what we consider to be Norwid's ideas about "female issues"”

[...] women of this period, that is Polish women, are most often persons of angelic attributes-I repeat it with absolutely no irony: angelic attributes. In the presence of Angels, time is not a requirement, work is something incomprehensible, and a tragedy is a song (Letter to Trębicka, c. a. 28 August, 1857, VIII, 329-320).

But such customary interpretative procedures not only do not help us in understanding the second stanza of "Three Stanzas", they also make understanding impossible. If we accept that at the level of biographical references the poem is connected with Maria Kalergis, we must take into consideration that Norwid, as early as July of 1848 , freed himself from his naive delusion about this person. In another letter to Maria Trębicka he wrote about himself as about a man who:

Saw [...] foreheads of Greek marble semi-gods covered with soft webs and satanic wings of peacocks' feathers tied to the most beautiful of shoulders...

(Letter to Trębicka, 3 July, VIII, 67). 
While the subject of "Three stanzas" says:

I nie mów ziemskie iż są marne cele

Lec żyj-raz-przecie. $(\mathrm{I}, 222)^{13}$

After all, the very Paris season of 1847-48 was the season of Maria Kalergis's debut, about which Norwid, as we see, was quite well informed, and it must have given him clear evidence that she was a person who did not require any special encouragements, but only appropriate circumstances. He must have known that the reason for his failures was not the conventions of "holiday emotions", or the apparent aspiration of this lady to achieve spiritual perfection. Simply, he had no chance in a competition in which high social status was required even for a start. A person like Norwid did not in any way fit into "the horizon of expectations" of the lady who was honoured (although in a rather fleeting way) by general Cavaignac - the dictator of Paris during the June uprising, a prime minister and Louis Napoleon's rival in the presidential election, or Theophile Gautier, an argbiter elegantiarium; the lady of whom the malicious Heine said, when he learnt that she was going to visit the Pantheon, "she is a Pantheon herself in which great men have rested". While in a poem stylized to look like an autobiographical settling of accounts there are accusations, which — when analysed in an autobiographical contextseem to be totally unfounded. Because these are not accusations of insincerity, falsehood, hypocrisy, vanity or the collector's attitude to men, which we detect in the quoted fragment about "satanic wings tied to the most beautiful of shoulders"; these are accusations about subservience to conventions and escapist bigotry. Obviously, neither of these reasons resulted in Norwid's failure, and he must have been aware of it for a long time. In a letter to August Cieszkowski written in November 1850 he ironically wrote:

[...] I expect [...] that, for example, such an explanation as has been used to explain the break in my relationship with Lady Maria that

13 "And don't say that earthly goals are bad,/But live! - once - really." 
I did not have ideas idealistic enough about friendship (!) - so, I expect such an explanation to be spread and other things in consequence. (VIII, 112)

The perversity of "Three Stanzas" is in the fact that contempt for the addressee has an unrealistic motivation (which is even more compromising for the victim), because Heine's bon mot on Maria Kalergis is, in a way, a complement; one may comment in the style of Chamfort in such a way: not every lady can boast of a bad reputation acquired thanks to "great men". Norwid, however, managed to avoid even a shadow of positive values. The addressee of the poem turns out to be an erotically frigid, frightened and limited bigot: anyway Maria Kalergis's devotion and piety were commonly known. Mickiewicz in his indignant, abusive sonnet "Pożegnanie" ("A Farewell”), was perhaps more brutal, but definitely less malignant. I allow myself a certain amplification in order to state that the structure of "Three Stanzas" is reminiscent of the parlour intrigues in the style of Dangerous Liasons. An exquisite revenge for humiliation.

A long-time friend of Norwid, Maria Trębicka, was also punished for the rejection of his marriage proposal. The strategy he selected was a bit similar, but not identical. The poem which begins with the line "Smutną zaśpiewam pieśń" ("I will sing a sad song") (dated by Gomulicki February/March 1852, XI 591, but the date is probably wrong...) continues with the theme of contempt "pour la femme en general", initiated in the quoted 1847 letter:

Aż - pogardziłem... może nie w czas - nie wiem,

Czy jest pogardy jaki Jubileusz?

Czyli dość trafnie gardzę? [...]

$$
(\mathrm{I}, 257)^{14}
$$

This time, however, Norwid used bigger guns:

\footnotetext{
14 “Till I despised...perhaps not in time - I don't know,/Is there some Jubilee of contempt?/So is my contempt correct?/”
} 
Straciłem wielką rzecz - uszanowanie

Dla płci, jak dawniej czynili poganie,

I do da onej zstąpiłem bez-wiary,

I wiem, że cała różnica kobiety

Przed-chrześcijańskiej na tym tylko leży,

Że tamte (mamże tu dodawać: nie Ty),

Że tamte tylko z wysokości wieży

Na dzień tryumfu kwiat miotały wonny,

Gdy spodem huczał wóz dwunastokonny,

A te na Pasji dzień...

$$
(\mathrm{I}, 258-259)^{15}
$$

As Kazimierz Wyka remarked, the quotation about Maria Kalergis could be substituted in those cases where he clearly referred to Maria Trębicka, and vice versa. The failure was the same, the accusations did not change.

This was not quite so - Norwid celebrated this "jubilee of contempt" in honour of Trębicka in a more dignified way and with more impetus. Because this was a Christian holiday, which happens around Good Friday ("the day of the Passion"). Seemingly suggesting that a difference between a Christian and a pagan woman is small, the subject of this poem voices something opposite-that Christian women, contemporary to him, in fact were inferior: ancient women had adored winners; contemporary ones celebrate with flowers people going to Golgotha. This vision is reminiscent not so much of the tradition of decorating sepulchres for Good Friday, but rather of the iconographic model of mocking the suffering Jesus. Therefore, the role of women in Norwid's 'jubilee' is somewhat horrible.

The motif of the Passion returned in the letter to Trębicka written in August 1858; it was not accidental that Norwid included in it a report

\footnotetext{
15 "I have lost a big thing - respect/For sex, as pagans used to,/And I descended there with no-faith,/And I know that the whole difference of a woman/Pre-Christian is only that,/That they (do I have to add 'not You')/That they from tops of towers/ In the day of triumph threw fragrant flowers, /While down thumped a cart drawn by twelve horses,/And these for the day of Passion ..."
} 
about a conversation on saint Veronica which had taken place "in Faubourg St, Gemain, in the grand French world":

[...] the issue was if saint Veronica had come from the populace-To which I answered:

I think that a holy person, whom we know mostly from the fact that she had wiped with her apron the face of a man going to the gallows, must have come from the world of the not well educated. Otherwise, she would probably not have done it, and she would have acted appropriately for her position, like, for example, Joseph of Arymathia, who came from a senatorial, aristocratic family, or Pilate's wife, who was also from the aristocracy.

I do not have time to write more, but this will explain to you what I understand as angelic attributes characteristic for Polish women, while I am, as you happen to know, a man who in his life, of all virtues regards humane virtues as the highest.

(VIII, 320)

The narrator of this letter, inscribing his persona in an iconographic type of ecce homo and denying his addressee "humane virtues" (including the reason itself-ironic "as you, Madam, happen to know") questions her membership in the Christian community. The reference to the New Testament in the poem and in the letter forms a clear message, also at the biographical level: this is an addressee, apparently Christian, who should have recognized an image of the suffering Jesus in the face of Norwid-and should have married him. Marriage is therefore presented here as the nineteenth-century equivalent of the merciful gesture of saint Veronica.

"Beatrix"-another appraising poem, dated 1860 and connected by Gomulicki with Norwid's recollections of Brygida Wierzbowska, whom he had apparently admired at the age of sixteen, presents a lay variant of heroic auto-creation. The frame lyric situation is an ironic dialogue of a poet with a lady who shows surprise because of the peculiar features of the poetry of her interlocutor: the lack in it, "of even a word about Beatrice".

The poet's reply starts with his questioning of her real acquaintance with his writings. The condescending attitude he has for her is 
connected with the very serious auto-presentation-it will be continued in the internal part of the story entitled: "Oda do kobiety" ("An Ode to a Woman"). The meta-literary reflection which precedes it sharpens the self-construction of the speaking subject, who can with the same brilliance mock a parlour conversation with his interlocutor and entertain himself by toying with literary conventions-in this case the object of the jest is a stylistic model coming from the fourth part of The Forefathers' Eve. While "An Ode to a Woman" begins as an ode to a girl:

Kiedy za kółkiem biegałaś po darni,

Cała w warkoczach, Mówiłem tobie: „Włos sobie odgarnij!” -

I łzym miał w oczach.

$$
(\mathrm{I}, 312)^{16}
$$

As early as in the third stanza of this ode, a boyish—but at the same time, if we look at it closely, a bold and sadistically frivolousphantasm appears:

Rad bym ci za to wziąść te złote sploty

I obciąć nożem -

Albo uknować jakie wielkie psoty

Z aniołem-stróżem...

$$
(\mathrm{I}, 313-314)^{17}
$$

This is supposed to be a punishment for what? Here jests end and serious traumas and sentiments begin:

Bo byłem smutny - a kto przyszedł do mnie?

Nie ty - o pani!

\footnotetext{
16 "When you chased a wheel on the grass,/All in plaits,/I kept telling you "move your hair away,/And I had tears/in eyes."

17 "I would gladly take these golden plaits,/And cut them with a knife,/Or prepare some jests/With the guardian angel."
} 
Gdy krew i ogień, i fala koło mnie Wrzały z otchłani...

$$
(\mathrm{I}, 314)^{18}
$$

The tragic mask the subject puts on becomes more and more heroic:

I smutki ludzkie, prawie smutki Boże -

$\mathrm{Zn}$ a m po nazwisku;

Zawiści c h u d e brałem na obroże

W p i e ki eł ognisku.

„Eurydyce! - miałbym mówić prawo -

Pozdrów mię, proszę...”

I Andromacy rzec: „Ksieni! łaskawo

Patrz, ile znoszę...”

Nie jak Eneasz, ja piekielne groty

Przeszedłem - o! nie;

Ilu żałowaliście mi rózgi-złotej,

I z i ó $\nmid$ na skronie. ${ }^{19}$

In the poem "Beatrix" we clearly find a permanent tendency in Norwid's poetic imagination, the same one which is only lightly marked in "Three Stanzas", and which is a bit stronger in the poem to Maria Trębicka, and even more stronger in letters to her-this tendency is the freeing in the erotic context of self-awareness of the speaking subject in the direction of heroic imaginings with a mythological and hagiographic twist. What is more, this poem allows us to see very clearly that between Norwid's attitudes to women in general and to the women he was personally interested, and

\footnotetext{
18 "Because I was sad - and who came to me?/ Not You, O Lady!/When blood and fire and wave next to me/Seethed in an abyss."

19 "And human sorrows, almost God's sorrows -/I know by name/Lean envies I took on leashes/In the fires of hells/Eurydice! I might have the right to say,/Acknowledge me, please.../And to say to Andromache: Your Highness/See how much I bear./Not as Enneas, I have come through hell's caves, o - no!/How many golden rods you begrudged me/And herbs on a forehead."
} 
to the society for which he wrote and painted, expressed in literary terms-there exists a strong analogy.

G d y m nogę bosą stawił z dumą wielką

Na zamieć czasów,

A nie splamiłem ci łzy mej kropelką

Wstążek, atłasów!...

$$
(1,313-314)^{20}
$$

The observation arises that these declarations, stressing the loneliness, but also the autonomy of a speaking subject who owes nothing to women and to whom he does not owe anything strangely resembled the declaration included in the poem opening Vade-mecum "Klaskaniem mając obrzękłe prawice” (“The People’s Hands were Swollen with Applause")

Nor did I take from you, giants of stardom!

$$
(\mathrm{II}, 15)^{21}
$$

Many statements scattered in Norwid's letters also resemble this declaration, like the one that he had nothing in common with the Polish community (for example in a letter to Piort Semenka dated 16 August 1857, see vol. VIII, 314-315). The model Norwid constructed: heroism of lonely endeavours - the indifference or reluctance of those around him, equal with rejection-compensatory pride-feeling of contempt; all these integrate in Norwid's writings a few levels of an artist's existence: the search in an area of poetic language, his financial situation, reception of his works and experience in the area of erotic relationships. Such a homologation is already seen in the poem "The People's Hands Were swollen with Applause". Poetic meta-declaration changes into a reflection of social and ideological context, and finally moves in the direction of "women enchanted

\footnotetext{
20 "When I proudly put my bare foot/Against the snowstorm of times,/And I did not stain with my tears/Ribbons and satins."

21 Cyprian Norwid, Poems - Letters - Drawings, trans. by Jerzy Peterkiewicz, Carcanet, Manchester, 2000, 45.
} 
dead/Thousands of formulas". ${ }^{22}$ An artist speaking in this poem, looking at these women with indifference and totally impervious to their charms, is not a consistent construct. Because in the next stanza, taking on in a different tone a theme-seemingly-exhausted by this declaration, he reveals the compensatory background of his apparent "lack of passion"”

Nic nie uniósłszy na sercu, prócz szaty -

Pytać was-nie chcę i nie raczę: k a t y !. .

$$
(\mathrm{I}, 315)^{23}
$$

The mask of the "lack of passion", therefore, hides a deep disappointment and the feeling of injustice. "An Ode to a Woman" also ends with an insult:

Dlatego znam cię, R e a l n o ś c i - w d ow o!

I znam twą śliczność,

I powiem tobie tylko jedno słowo:

„Tyś... jak... publiczność.”

$$
(\mathrm{I}, 315)^{24}
$$

The social reception of his work and an "erotic" reception of a non-conformist artist turn out to be two sides of the same coin. In the closing formula there is an aura of a brutal pun; a potential semantic reference to the phrase "a public woman".

Norwid's literary and journalistic texts had a certain standard imbedded of the poet's expectations towards social surroundings. These expectations were not small: a writer has a moral duty to ignore "offended in the inscrutable past" (II, 16), even if they constitute the majority, he has the right "to show the negative aspects of old

\footnotetext{
22 Ibid., 46.

23 "Taking nothing in my heart but garment/- I do not want or bother to ask you - executioners!?”

24 "That is why I know you: Widow of Reality!/And I know your beauty, And I will tell you just one word:/ You...like...audience."
} 
Customs," 25 if he sees its debilitating influence on the community, and at the same time he has a right to expect recognition and acceptance, which are owed to him, because he is right, even if he is not able to prove it in a commonly accepted way. He has the right to expect to be paid for his intellectual endeavours, although his work is not the result of social order, and the literary market is not to be fully governed by the rules of capitalism. There are so many contradictory things which could be found in Norwid's statements and auto-commentaries on these issues, and a hypothesis of Zofia Stefanowaka that Norwid consciously modelled the status of a writer in a manner internally contradictory remains valid. ${ }^{26}$

This dialectic logic, however, has its extension in his perception of women and in his ways of interpreting failures in spheres of eroticism. A woman is "the highest binding ("Emancipation of Women") between an individual an a community, which means that she herself is not in essence an individual, but is obliged to support the socialization of a real, that is male, 'I' in the same manner as the society should provide an intellectual with financial support even - or maybe particularly-when this intellectual openly breaks with "old customs". According to this analogy, the right of a woman to choose a partner is-in the moral sense-limited, and therefore the rejection of an emotional offer is in some cases scandalous and vile, and should be stigmatized. So, eventually, both the status of a writer in the face of his audience and the situation of a creative individual, looking for the emotional binding and closeness of a woman, are subject to the same interpretative rule: "You...like...audience".

This rationalization of the attitude of restitution in Norwid's texts becomes both discursive and pictorial, and that is why the erotic aspect of his literary imagination seems to be not very disinterested. A woman appears to be a rare commodity, which at the figurative level is accomplished through the stylization of 'a marble statue type'.

\footnotetext{
25 See ibidem.

26 See Z. Stefanowska, Pisarz wieku kupieckiego i przemysłowego, in Eadem, Strona romantyków. Studia o Norwidzie, Lublin 1993.
} 
Such a stylization was for the first time used by Norwid in the poem "Marmur-biały" ("Marble-White"), based on the concept of a parallel between the society of ancient Greece, ungrateful and cruel towards its great men, and "a blue eyed lady with a plain profile of Minerva", equally careless about the subject speaking in this poem (see, I, 100101). Here we had an early form of a heroic valuation of the speaking 'I', who will have a stronger motivation and will develop in terms of pictures in later texts: if the figure of "a lady with a plain profile of Minerva" stands for "beautiful Greece-then, through the power of metaphorical parallel, a sad admirer is equal with Homer, Phidias, Miltiades, Themistocles, Thucydides, Cimon, Aristides, Fokion, and finally with Socrates. For a while, the promotion to this society is ensured by being an admirer of a lady not willing to reciprocate emotions, but in "Beatrix" the Ancient costume will be cut more accurately and will be finished more diligently. The subject speaking there will recognize himself in the figures of Orpheus and Hector, and compare himself with Aeneas; the justification for such autocreation will be provided-at least in the case of the first and third of heroes-by the motif of a descent to Hades:

Zawiści chude brałem na obroże

$\mathrm{W}$ piekieł ognisku. ${ }^{27}$

This declaration sends directly to the myth of Heracles-and the most difficult of his twelve works: the taming of Kerberos and taking him to the court of king Eurysteus in Mykenos. This aspect of Heraclean topic had some role to play in Mickiewicz's "Ode to Youth"

No Heart, no Spirit - Lo! cadaverous crowds!

O Youth! Pass me thy wings,

27 "Lean envies I took on leashes/In the fires of hell." 
And let me o'er the dead earth soar;

Let me vanish in delusion's clouds, ${ }^{28}$

What was a postulate for maximal goals in Mickiewicz's poem, in Norwid's poem becomes a story about achievement. But it should not be forgotten that this story is a rhetorical figure of narratio inscribed into "An Ode to a Woman" and has an accusatory function. If a speaking subject exceeds mythical heroes, that is not his choice, but because he was sentenced to complete loneliness. He is Orpheus without Eurydice, Hector without Andromache, Enneas without Lavinia. He went through "hellish caves", not staining anyone's "ribbons, satins" and not tearing the "gaseous veil" to wipe his forehead. Therefore, his triumph is bitter, but it is a triumph anyway. "I did not use medicines and medics"-wrote Słowacki in a lyric fragment. In Norwid's poem "medics" were replaced by "women".

The structure of Norwid's picture of 'empirical' woman differentiated from 'postulated' women is doubly oxymoronic: on the one hand metaphors of cold, marble statues (allusive simile to "rock" and "feudal Towers" in "A Painter Out of Necessity"), and on the other all these ribbons, satins, veils ("Beatrix", "Give Me a Blue Ribbon..”.) coiffures, flowers, frills, and thirdly, the phantasmal, unrealistic character of their existence. "I know you, Widow-Reality," says the subject of "An Ode to a Woman". In "The People's Hands Were Swollen with Applause" we may see a fluid transition-even though it is oxymoronic. Marbles become phantasms.

Touching this or another's marble hand,

Moving a dress-fold from its stony sweep,

Over her head a night-moth flew and fanned,

Its wings and fell - they all left, half asleep... ${ }^{29}$

Therefore, they depart as apparitions, but this is not the end-they will return in the next stanza in yet another form:

\footnotetext{
28 Adam Mickiewicz, "Ode to Youth", transl. by Jarek Zawadzki, https:// en.wikisource.org/wiki/Ode_to_Youth, retrieved on 5.11.2018

29 Cyprian Norwid, Poems..., op. cit., 46.
} 
Pytać was nie chę I nie raczę-katy. ${ }^{30}$

So, there also exists the fourth side of the picture-cruelty-and one more oxymoron: passive, dreamy female phantoms depart in order to reappear in the role of executioners.

All this, spoken in the first person, constructs a personal autobiographical myth of Norwid. The restitutionary aspect of this myth could be tackled from a wider cultural perspective. Norwid's literary imagination included one of the fundamental topics of European literature: a woman as a prize for a warrior. ${ }^{31}$

Although in Shiller's ballad “A Glove”, paraphrased by Mickiewicz and included in Ballady $i$ romanse (Ballads and Romances), this motif underwent sharp revision, it was willingly used by authors of nineteenth century historical novels. Let us take Sienkiewicz: Ligia is a prize for Vinicius for becoming a Christian and his trust in God. Helena is a prize for Skrzetuski for faithful and very dangerous service to the duke Jeremi and Poland; Oleńka is a salary for Kmicic for destroying a huge Swedish gun and being blistered by a torch. The functioning of this model in Norwid's literary imagination could also be grasped in an indirect way. Let us look closely at his accusations about the "lack of women in Polish literature", which he used while referring to a heroine of Konrad Wallendrod:

Everybody knows that Aldona sings from a locked tower, out of which one cannot go and not to be seen as less beautiful to man, since he

\footnotetext{
30 Ibidem, “I don't want to ask you and I don't bother - executioners!”

31 Heracles after ascending to Olympus receives a wife-Hebe-the goddess of youth. Perseus kills a dragon blasting Ethiopia and marries Andromeda. Odysseus returns to power in Ithaca and gets Penelope back. The young king Arthur with forty comrades supports the ruler of Kerokez, destroying an army of Romans and Alemans, and then moves to rescue his own lands blasted by pagan Sains; he wins and simultaneously forces his rebelling vassals into submission, and proving his worth as a knight and a ruler receives the hand of the beautiful Guinevere) (See J. Boulenger, La Légende du Roi Arthur) The popular motif of fairy tales: competition for the hand of a king's daughter, which is received with half of the kingdom.
} 
started to live-and rightly so, because one has to be dead for such great love subtleties.

(Letter to do Maria Trębicka, 20 Novermber September 1853, VIII, 197

Aldona is nothing-either she is a caricature drawn with Raphael's brush, who says to a man, when he is burdened by the age and the world that (she does not show herself because she has not done her hair): "Be to me great and famous, and powerful, but give me peace, I do not want to know you and see you and will not give you a glass of water and go to the deuce", so that I don't know what she is praying to, this Christian, who is neither Martha nor Magdalene! (Letter to do Maria Trębicka, 15 September 1856, VIII, 287)

The peculiarity is that while Norwid was mocking Mickiewicz, he was showing at the same time that he did not quite understand the sense of Konrad Wallendrod. It is known that the theme of Aldona was handled in such a way that stylistic reservations could be made -the sentimentalist emotionality of Aldona was described in detail by Henryk Schipper in his 1926 book, while psychological functional analysis was undertaken by Kleiner. But it would be difficult to accuse Norwid of having read Kleiner not carefully enough. However, he could have read Mochnacki more carefully, and his brilliant critique of the love theme in this poem.

Briefly speaking: the whole love affair of Alf and Aldona has a bad effect on the whole text. Aldona, even at the end, flirts in a way unbecoming a female hermit. [...] Aldona does not want to fall in ecstasy into Alf's arms-what does she want? She wants to see him alive and to speak with him every evening: in this way to sweeten all her sufferings. [...] What is more, Aldona wants to have not only Alf, but the whole of Lithuania in miniature, next to her tower [...]

This is exactly the same, word for word, as in Wegle's Swiss Family. Did not Mickiewicz think that it was all petty, little, that it is affect, and almost the same type of longing as city dwellers have for 
beautiful nature in the country. [...] How much psychological and poetic untruth ${ }^{32}$

Norwid repeated the accusations of Mochnacki, trivializing them in an awful way. Mochnacki was concrete, despite his irony, and he showed Mickiewicz's structural, stylistic and psychological weaknesses, while Norwid questioned the very plot of the text. But, after all, Mickiewicz's idea, to construct this miserable episode near the tower, because it turned out that it was too late for both lovers, that the return to the past is impossible-this is a sensible idea on the plane of the script, fulfilling the image of this protagonist as consistently tragic. For Norwid, the fact that Aldona will not descend from her tower and will not throw herself into Alf's arms, is not an issue of the psychological reliability of this character, but a moral issue. Attacking this character, Norwid seemed to be unaware that this is exactly a literary character which fulfils-in a better or worse way-a concrete function in the plot; he commented on her behaviour as if she had been one of the parlour coquettes he knew personally, one of the "widows of Reality". It seems that Norwid wanted a different version of Konrad Wallenrod in which Mickiewicz should have sent his protagonists to Lithuania to live long and happily.

It seems that Norwid's objection, not aesthetic, but really moral, concerned the issue that Alf-Walter did not receive the prize he deserved for his deeds. Love is, obviously, this prize-real and active, in contrast to the "non-material emotionality" he was writing about in the same letter. Such a love should be morally earned, but once a man has earned it, then he has the inalienable right to a woman, and a woman should not dodge and fuss. As Aldona did..., or Maria Trębicka. In Norwid's poetic and prosaic imagination, if a woman does not want to be prized for moral virtues and artistic talents, all the worse for her-if she were a truly Christian woman, then she would want it. And since she could not see in her admirer Orpheus, Hector, Aeneas or a martyr and the follower of Christ, then she

32 M. Mochnacki, O literaturze polskiej w wieku dziewiętnastym, ed. by Z. Skibiński Łódź 1985, 130. 
should be stigmatized in an exemplary fashion. And even scolded. So that she should know that she would not be rehabilitated by sending a cheap picture of the Mother of $\operatorname{God}^{33}$ packaged in a hypocritical blessing.

33 "Thank you for this picture; it is not faithful and made in the same way as all objects of religious art today, that is-with desecration. [...] This picture (an imitation of Murillo) there is no "crown made of twelve stars", nor is she "clothed in the sun", nor you can see in her face that she is pregnant - and this all was written by the Author of a New Testament and the Saviour's close friend. But this is how things are treated today! So much for the picture." (Letter to Maria Trębicka, August, 1857, VIII, 319). 